\title{
ZMIENNOŚĆ STRUKTURY KREDYTOWEJ A WIELKOŚĆ BANKU NA PRZYKŁADZIE WYBRANYCH BANKÓW SPÓŁDZIELCZYCH
}

\author{
Emilia Stola \\ Katedra Finansów \\ Szkoła Główna Gospodarstwa Wiejskiego w Warszawie \\ Artur Stefański \\ Instytut Finansów \\ Wyższa Szkoła Bankowa w Poznaniu
}

\section{WYŻSZA SZKOŁA BANKOWA W POZNANIU}

\begin{abstract}
Abstrakt. Współcześnie banki spółdzielcze chcąc zachować konkurencyjność w sektorze bankowym względem banków komercyjnych oraz innych instytucji bankowych i para-bankowych, dążą do zaspokojenia potrzeb kredytowych klientów. Wydaje się, że banki udzielając kredytów inwestycyjnych, które w ujęciu ilościowym charakteryzują się mniejszą dynamiką, niż kredyty detaliczne to jednak jednostkowe zaangażowanie banku w tej sytuacji jest relatywnie wyższe. W związku z tym powstaje pytanie czy struktura rodzajowa udzielonych kredytów jest determinowana przez wielkość banku. Celem opracowania było określenie poziomu zróżnicowania struktury rodzajowej kredytów ze względu na wielkość banków. Przeprowadzone grupowanie banków i analiza wariancji wskazały na istnienie istotnych statycznie różnic w przypadku struktury kredytów inwestycyjnych oraz operacyjnych i instrumentów dłużnych, natomiast w pozostałych przypadkach, w tym kredytów konsumpcyjnych nie potwierdzono różnic w strukturze w zależności od wielkości banku.
\end{abstract}

Słowa kluczowe: banki spółdzielcze, struktura portfela kredytowego, kredyty inwestycyjne. 


\section{WSTĘP}

Kredyty bankowe, zaliczane do operacji kształtujących bankowe aktywa, należą do podstawowych produktów sprzedawanych przez banki. Operacje te umożliwiają bankom uzyskanie przychodów do pokrycia ponoszonych kosztów, zarówno pozyskanego pieniądza, jak i kosztów funkcjonowania instytucji [Capiga i in., 2005, s. 122]. Kredyty są nieodzownym elementem współczesnej bankowości, choć ich znaczenie jest obecnie nieco mniejsze niż w początkach powstania bankowości, z tego względu, że rozwój przedsiębiorczości wymusił także rozwój oferowanych przez banki usług [Janc i in., 1999, s. 34], w tym związanych z finansowaniem zapotrzebowania na środki pieniężne.

Samo pojęcie kredytu jest pojęciem ekonomicznym, powodującym powstanie stosunku ekonomicznego między kredytodawcą a kredytobiorcą [Jaworski i in., 2005, s. 287] zakładającym okresowe przesunięcie siły nabywczej od wierzyciela do dłużnika w uzgodnionym podmiocie gospodarczym, wysokości, obejmujące odsetki jako wynagrodzenie za ekonomiczne używanie kredytu w okresie na jaki został udzielony [Wiatr 2008, s. 15]. W większości przypadków udzielania kredytów przez banki, żądane jest zabezpieczenie kredytu, choć istnieją przypadki braku ustanowionego oddzielnego zabezpieczenia [Słownik finansów i bankowości 2008, s. 174], np. w przypadku kredytów w kartach kredytowych dla osób fizycznych. Z kolei pojęcie kredytu bankowego zostało zdefiniowane w Prawie Bankowym poprzez sformułowanie definicji umowy kredytowej, zgodnie z którą „bank zobowiązuje się oddać do dyspozycji kredytobiorcy na czas oznaczony w umowie kwotę środków pieniężnych z przeznaczeniem na ustalony cel, a kredytobiorca zobowiązuje się do korzystania z niej na warunkach określonych w umowie, zwrotu kwoty wykorzystanego kredytu wraz z odsetkami w oznaczonych terminach spłaty oraz zapłaty prowizji od udzielonego kredytu" [Ustawa Prawo bankowe, art. 69].

Zgodnie z polskim prawem kredytów mogą udzielać tylko banki. Akcja kredytowa banku występuje wówczas, kiedy można ustalić cel jej udzielenia, co tym odróżnia kredyt od pożyczki [Dobosiewicz 2003, s. 213]. Kredyty stanowią fundamentalny składnik aktywów pracujących banku, jak również są istotnym źródłem dochodów dla banków, głównie przez przychody odsetkowe i marże. Ponadto działalność kredytowa banku zawsze stanowiła największy obszar aktywności tych instytucji, co wymaga konieczności wypracowania odpowiedniej polityki kredytowej [Capiga 2008, s. 157]. Banki zazwyczaj prowadzą wieloelementową politykę portfela kredytowego. Polega ona na tworzeniu składu portfela w sposób zgodny z interesami banku, budując aktywność kredytową na dziedzinach czy wybranych segmentach klientów. Udzielanie kredytów to nie tylko proces zarabiania pieniędzy przez banki, ale także realizowanie szeregu funkcji gospodarczych, jak 
m.in. kreacji pieniądza, po przez wprowadzenie do obiegu nowych środków pieniężnych [Grzywacz 2006, s. 127].

Kredyty bankowe mogą być klasyfikowane według różnych kryteriów, w literaturze przedmiotu można spotkać bardzo rozbudowane klasyfikacje kredytów bankowych, niekiedy dochodzi też do wzajemnego przeplatania się czy nakładania odmiennych typów kredytów. Choć wskazane kryteria nie wyczerpują możliwości klasyfikacji kredytów to w literaturze przedmiotu zaliczają się one do najbardziej popularnych, zalicza się do nich: podmiot, przedmiot, formę kredytu, okres kredytowania, sposób wykorzystania i obsługi, sposób zabezpieczenia, walutę, liczbę banków kredytujących, zasady oprocentowania, częstotliwość wykorzystania i obsługi długu, preferencyjność, skalę akceptowanego ryzyka, czy jakość ekspozycji kredytowych [Wiatr 2008, s. 18.]. W podobny sposób budowane są portfele kredytowe banków, najczęściej segmentuje się je ze względu na rodzaj kredytobiorcy, branże i region, w których działa ale również ze względu na przeznaczenie kredytów, walutę oraz ustanawiane zabezpieczenia [Krysiak i in., 2015, s. 37]. Na potrzeby niniejszego opracowania wykorzystane zostanie kryterium przedmiotu oraz formy. Choć podstawowy podział według pierwszego z tych kryteriów zakłada wydzielenie kredytów obrotowych i inwestycyjnych, a według drugiego, kredytów gotówkowych oraz bezgotówkowych to jednak w dalszej części artykułu zastosowany zostanie podział zgodny z pozyskanymi u źródeł danymi statystycznymi, gromadzonymi przez Związek Rewizyjny Banków Spółdzielczych - gdzie te nakładanie się różnych kryteriów wspomniane wcześniej jest doskonale widoczne. Portfel kredytów dla instytucji niefinansowych został podzielony na następujące grupy: kredyty operacyjne, kredyty w kartach kredytowych, kredyty konsumpcyjne, kredyty na zakup papierów wartościowych, kredyty inwestycyjne, kredyty samochodowe oraz instrumenty dłużne i inne.

Spośród wydzielonych grup kredytów na szczególną uwagę zasługują dwa, które wydaje się, powinny zależeć od wielkości banku, tym samym rozwoju jego oferty. Są to kredyty w kartach kredytowych oraz kredyty inwestycyjne. Te pierwsze związane są z wyższym poziomem organizacyjnym i technologicznym banku, a także szerszym zasięgiem oddziaływania, zatem można oczekiwać, że będą występowały częściej w bankach większych. Z drugiej jednak strony są to zwykle relatywnie drobne kwoty zaangażowania, a zatem przyrost ilościowy nie przełoży się na wzrost wartościowy, a tym samym udział w strukturze portfela kredytowego banków. Z drugiej strony kredyty inwestycyjne, które w ujęciu ilościowym nie rozwijają się zwykle tak dynamicznie jak inne, szczególnie detaliczne typy kredytów, to jednak pod względem jednostkowym wartość kredytu jest relatywnie wyższa. Dodatkowo banki chcąc zachować konkurencyjność na rynku, dążą do zaspokojenia coraz większych potrzeb inwestycyjnych klientów, co powoduje, że jest to raczej domena banków większych. To prowadzi do założenia, że w bankach więk- 
szych udział kredytów inwestycyjnych powinien być wyższy. Tym samym można oczekiwać, że struktura rodzajowa kredytów będzie zróżnicowana za względu na wielkość banku, co jest hipotezą postawioną w niniejszym opracowaniu (H1).

\section{METODY BADAŃ}

Celem opracowania było określenie poziomu zróżnicowania struktury rodzajowej kredytów dla klientów sektora niefinansowego ze względu na wielkość banków na przykładzie wybranych banków spółdzielczych. W artykule postawiono następującą hipotezę badawczą: struktura rodzajowa kredytów zróżnicowana jest za względu na wielkość banku. W artykule wielkość banków zdefiniowano pod względem wartości aktywów.

Na dzień 31.12.2016 roku zgodnie z danymi KNF działalność bankową prowadziło 558 banków spółdzielczych [Komisja Nadzoru Finansowego, 2016]. Na potrzeby przeprowadzenia analizy wylosowano dane 56 banków spółdzielczych (co stanowiło 10\% populacji wszystkich banków spółdzielczych, funkcjonujących w polskim sektorze bankowym), które gromadzone są i przetwarzane przez Związek Rewizyjny Banków Spółdzielczych. Uwzględniono stan z grudnia 2015 roku. Banki zostały podzielone na kwartyle ze względu na wartość sumy bilansowej, a następnie $w$ wydzielonych grupach ustalono średnie udziały poszczególnych typów kredytów, po czym wykorzystując testy różnic ustalono czy między grupami banków występują różnice w strukturze kredytów.

Wśród metod wykorzystano analizę wariancji z założeniami klasyfikacji pojedynczej [Hill, Lewicki 2006, s. 45] z weryfikacją hipotezy zerowej o jednakowych średnich w grupach wobec hipotezy alternatywnej, że co najmniej dwie średnie różnią się między sobą. W celu sprawdzenia założenia jednorodności wariancji wykonano test Levene'a. Natomiast do zweryfikowania, w której grupie banków średnie różnią się między sobą istotnie, wybrano test rozsądnie istotniej różnicy (RIR) Tukeya, ze względu na porównywalność par średnich. Wszystkich obliczeń wykonano na pakiecie statystycznym firmy StatSoft STATISTICA 12.

\section{ZANCZENIE KREDYTÓW W BANKOWOŚCI SPÓŁDZIELCZEJ}

O znaczeniu działalności kredytowej w bankach decyduje nie tyle wielkość bezwzględna wolumenu kredytowego, ale udział wartości udzielonych kredytów w sumie bilansowej oraz udział odsetek od udzielonych kredytów i pożyczek w przychodach banków.

Udzielanie kredytów jest podstawową czynną operacją bankową i czynnością bankową sensu stricto [Zaleska 2013, s. 79]. To jak kredyty bankowe są bardzo 
ważną usługą w bankach, niech świadczy choćby udział kredytów i pożyczek w aktywach banków, relacja zobowiązań pozabilansowych o charakterze finansującym czy gwarancyjnym wobec sumy aktywów (co ilustrują wykres 1 oraz tabela 1), a także udział przychodów z tytułu kredytów i pożyczek w przychodach odsetkowych (wykres 2 oraz tabela 2) lub też ich relacja do innej ważnej grupy przychodów bankowych, tj. opłat i prowizji (tabela 2).

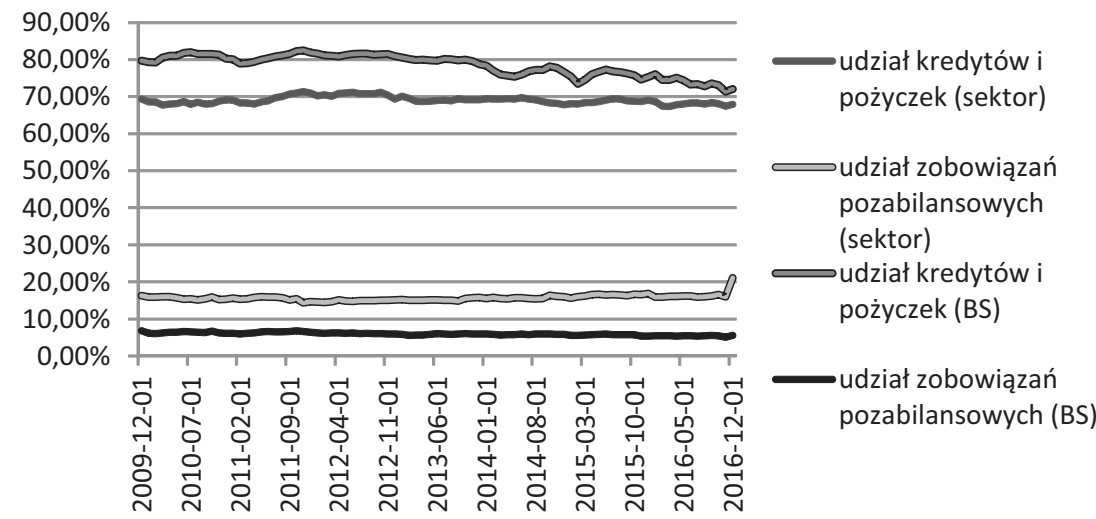

WYKRES 1. Relacja kredytów i pożyczek oraz zobowiązań pozabilansowych wobec sumy bilansowej banków spółdzielczych oraz sektora bankowego w Polsce w latach 2009-2016 [\%]

Źródło: www.knf.gov.pl/opracowania/sektor_bankowy/dane_o_rynku/Dane_miesieczne.html, dostęp 31.03.2017.

W okresie od grudnia 2009 roku do grudnia 2016 roku kredyty i pożyczki były dominującą grupą aktywów banków działających w Polsce. Ich średni udział w tym czasie stanowił 69,1\% (wykres 1), przy odchyleniu standardowym wynoszącym 1\%. Warto też dodać, że rozpiętość między wartością najwyższą a najniższą wskaźnika struktury w tym czasie to zaledwie 4,1 punkty procentowe. Wskazuje to na wysoki i stabilny udział kredytów i pożyczek w sumie bilansowej banków w Polsce. Warto dodać, że ten odsetek jest w segmencie banków spółdzielczych powyżej średniej sektora bankowego. Średnia wynosi 78,5\%, przy odchyleniu standardowym 2,9\%. Rozpiętość między najwyższą a najniższą wartością wskaźnika struktury wynosi 11,1 punktu procentowego. Na podkreślenie zasługuje też fakt, że w ostatnich latach obserwuje się systematyczny spadek znaczenia kredytów i pożyczek w sumie bilansowej banków spółdzielczych, choć pozostają one aktywem dominującym. Gdyby uwzględnić nie tylko kredyty i pożyczki, ale także inne należności finansowe banków w tym np. leasing finansowy to wskaźniki struktury są jeszcze wyższe i średnio w sektorze bankowych wynosił w badanych latach 70,7\%. Dodatkowo na łączne ryzyko kredytowe wpływają także udzielone 
TABELA 1. Relacja kredytów i pożyczek oraz zobowiązań pozabilansowych wobec sumy bilansowej banków spółdzielczych oraz sektora bankowego w Polsce w latach 2009$-2016[\%]$

\begin{tabular}{|c|c|c|c|c|c|c|c|c|c|c|c|c|}
\hline \multirow[b]{2}{*}{$\begin{array}{l}\text { Relacja wobec } \\
\text { sumy aktywów }\end{array}$} & \multicolumn{8}{|c|}{ Lata } & \multirow[b]{2}{*}{ 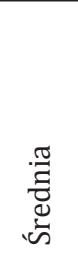 } & \multirow[b]{2}{*}{$\Xi$} & \multirow[b]{2}{*}{$\sum_{\Sigma}^{x}$} & \multirow{2}{*}{ 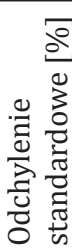 } \\
\hline & 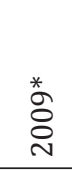 & $\begin{array}{l}\stackrel{\circ}{\sim} \\
\stackrel{\sim}{N}\end{array}$ & $\underset{\sim}{\stackrel{\sim}{\circ}}$ & $\underset{\sim}{\stackrel{\sim}{\sim}}$ & 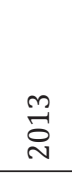 & $\underset{\sim}{\stackrel{+}{\circ}}$ & $\stackrel{\text { L }}{\underset{ᄋ}{\circ}}$ & $\begin{array}{l}0 \\
\stackrel{\sim}{\circ} \\
\sim\end{array}$ & & & & \\
\hline $\begin{array}{l}\text { Kredyty } \\
\text { i pożyczki } \\
\text { (sektor) }\end{array}$ & 69,3 & 69,1 & 71,0 & 69,3 & 69,2 & 67,8 & 69,1 & 68,0 & 69,1 & 67,3 & 71,4 & 1,0 \\
\hline $\begin{array}{l}\text { Zobowiązania } \\
\text { pozabilansowe } \\
\text { (sektor) }\end{array}$ & 16,3 & 15,3 & 14,7 & 15,1 & 15,8 & 16,0 & 16,9 & 21,1 & 15,7 & 14,4 & 21,1 & 0,8 \\
\hline $\begin{array}{l}\text { Kredyty } \\
\text { i pożyczki (BS) }\end{array}$ & 79,7 & 80,3 & 81,9 & 81,0 & 78,7 & 76,7 & 75,3 & 73,8 & 78,5 & 71,3 & 82,4 & 2,9 \\
\hline $\begin{array}{l}\text { Zobowiązania } \\
\text { pozabilansowe } \\
\text { (BS) }\end{array}$ & 6,8 & 6,1 & 6,4 & 5,9 & 5,9 & 5,9 & 5,4 & 5,6 & 6,0 & 5,1 & 6,9 & 0,4 \\
\hline
\end{tabular}

*)wybrane dane na koniec lat

Źródło: www.knf.gov.pl/opracowania/sektor_bankowy/dane_o_rynku/Dane_miesieczne.html, dostęp 31.03.2017.

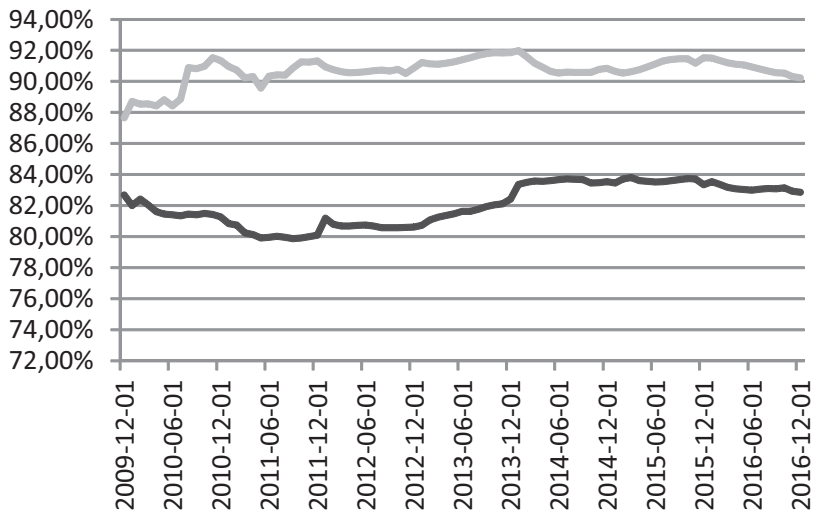

udział odsetek od kredytów (sektor)

udział odsetek od kredytów (BS)

WYKRES 2. Udział odsetek od kredytów i pożyczek w przychodach odsetkowych w latach 2009-2016

Źródło: www.knf.gov.pl/opracowania/sektor_bankowy/dane_o_rynku/Dane_miesieczne.html, dostęp 31.03.2017. 
TABELA 2. Udział odsetek od kredytów i pożyczek w przychodach odsetkowych (\%) oraz relacja przychodów odsetkowych do przychodów z tytułu opłat i prowizji w latach 2009$-2016$

\begin{tabular}{|c|c|c|c|c|c|c|c|c|c|c|c|c|}
\hline \multirow[b]{2}{*}{ Wyszczególnienie } & \multicolumn{8}{|c|}{ Lata } & \multirow[b]{2}{*}{.ొٌ } & \multirow[b]{2}{*}{$\Xi$} & \multirow[b]{2}{*}{ 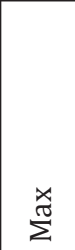 } & \multirow{2}{*}{ 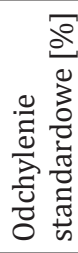 } \\
\hline & $\begin{array}{l}\text { \&े } \\
\text { ஓ }\end{array}$ & $\begin{array}{l}\stackrel{0}{N} \\
\stackrel{\sim}{\circ}\end{array}$ & $\underset{\sim}{\stackrel{\sim}{\circ}}$ & $\underset{\sim}{\stackrel{N}{\sim}}$ & $\stackrel{m}{\stackrel{\sim}{N}}$ & $\underset{\sim}{\stackrel{+}{\circ}}$ & $\stackrel{\text { L }}{\stackrel{7}{\sim}}$ & $\begin{array}{l}0 \\
\stackrel{\circ}{\circ} \\
\text { N }\end{array}$ & & & & \\
\hline $\begin{array}{l}\text { Odsetki kredytowe/ } \\
\text { /przychody } \\
\text { odsetkowe (sektor) }\end{array}$ & 82,7 & 81,3 & 80,1 & 80,6 & 82,4 & 83,6 & 83,3 & 82,9 & 82,1 & 79,9 & 83,8 & 1,3 \\
\hline $\begin{array}{l}\text { Odsetki kredytowe/ } \\
\text { /przychody } \\
\text { odsetkowe (BS) }\end{array}$ & 87,7 & 91,4 & 91,3 & 90,9 & 91,9 & 90,9 & 91,5 & 90,2 & 90,7 & 87,7 & 92,0 & 0,9 \\
\hline $\begin{array}{l}\text { Przychody } \\
\text { odsetkowe/ } \\
\text { /prowizje i opłaty } \\
\text { (sektor) }\end{array}$ & 3,4 & 3,3 & 3,6 & 3,9 & 3,5 & 3,3 & 3,1 & 3,3 & 3,5 & 3,1 & 4,2 & 0,3 \\
\hline $\begin{array}{l}\text { Przychody } \\
\text { odsetkowe/ } \\
\text { /prowizje i opłaty } \\
\text { (BS) }\end{array}$ & 3,3 & 3,7 & 4,3 & 4,8 & 4,3 & 4,0 & 3,6 & 3,4 & 4,0 & 3,3 & 4,9 & 0,5 \\
\hline
\end{tabular}

Źródło: www.knf.gov.pl/opracowania/sektor_bankowy/dane_o_rynku/Dane_miesieczne.html, dostęp 31.03.2017.

zobowiązania pozabilansowe banków, a ich udział w sektorze bankowym w Polsce w ostatnich 8 latach wynosił 15,7\%, zaś w segmencie banków spółdzielczych $6 \%$. Liczby te wskazują na to, że kredyty bankowe oraz inne produkty kredytowe oraz związane z nimi ryzyko jest kluczowym zagadnieniem w bankowości.

Działalność kredytowa banków bezpośrednio oddziałuje na strukturę osiąganych przez banki przychodów (wykres 2). Udział odsetek od kredytów i pożyczek w sektorze bankowym w przychodach odsetkowych w latach 2009-2016 był bardzo wysoki, średnio wynosił 82,1\%, i stabilny (odchylenie standardowe wyniosło $1,3 \%$, a rozpiętość między najwyższą a najniższą wartością wskaźnika niespełna 4 punkty procentowe). W segmencie banków spółdzielczych ten udział jest jeszcze silniejszy - średnia ukształtowała się na poziomie 90,1\% i również stabilny. Jak istotne są przychody odsetkowe w działalności banków może potwierdzić wskaźnik relacji tychże wobec innej ważnej grupy przychodów tj. opłat i prowizji, który w badanym okresie wynosi średnio 3,5 dla sektora bankowego oraz aż 4 dla segmentu banków spółdzielczych. Warto zauważyć, że są to także stabilne wartości, o czym świadczą i odchylenie standardowe i rozpiętości między obserwacjami skrajnymi w badanym okresie. 


\section{WYNIKI BADAŃ}

Banki zostały podzielone na kwartyle ze względu na wartość sumy bilansowej, a następnie w wydzielonych grupach ustalono średnie udziały poszczególnych typów kredytów, po czym wykorzystując testy różnic ustalono czy między grupami banków występują różnice w strukturze kredytów. Na podstawie wyliczonych kwartyli oraz statystyk opisowych na wykresie 3 przedstawiono średnie wartości udzielonych różnych rodzajów kredytów w poszczególnych grupach banków. Grupa A odpowiada kwartylowi górnemu, w którym znalazły się banki o sumie aktywów wyższej niż 984 tys. Zł. Kolejna grupa - B, odpowiada kwartylowi 75\%, w której znajdują się banki o aktywach z przedziału powyżej $281 \mathrm{mln}$ zł do 984 mln. zł. Kwartyl 25\% odpowiada grupie C, do którego zaliczono banki o wartości aktywów z przedziału mln tys. zł poniżej 281 mln zł do 91 tys. zł. Grupa D to dolny kwartyl, w którym znalazły się instytucje o sumie aktywów poniżej $91 \mathrm{mln}$ zł. W przypadku średnich różnic w strukturze udzielnych kredytów między bankami pod względem wielkości tych instytucji największe rozróżnienie dotyczyło kredytów konsumpcyjnych. Najwyższy udział w tej grupie miały banki z grupy D $(13,40 \%)$, a więc o najmniejszej sumie aktywów. Jednocześnie w tym przypadku występuje tendencja malejącego udziału kredytów konsumpcyjnych ze względu na wielkość banku. W bankach grupy C, udział ten wyniósł 10,6\%, w grupie B około 8,2\% natomiast w grupie A, a więc bankach o najwyższej sumie bilansowej 7,5\%. Zależność ta nie występuje w przypadku pozostałych rodzajów kredytów. Udzielone kredyty inwestycyjne w strukturze portfela kredytowego zajmują podobny udział - średnio 34,3\%. Przy czym największy udział w bankach średnich z grupy $B(+2,1$ p.p.), natomiast najmniejszy $w$ bankach nieznacznie mniejszych z grupy $C(-1,8$ p.p.).

W ramach przeprowadzonej analizy, sprawdzono założenia, ze wariancje w różnych grupach są jednorodne przy wykorzystaniu testu Levene’a. W przypadku zmiennych kredyty konsumpcyjne, samochodowe oraz w kartach kredytowych test okazał się istotny, co oznacza, że wariancje były niejednorodne (tabela 3). Natomiast przy pozostałych rodzajach kredytów nastąpił brak podstaw do odrzucenia hipotezy zerowej o równości wariancji ( $p>0,5)$, co umożliwiło przeprowadzenie analizy wariancji.

W przypadku wybranych zmiennych do przeprowadzenia analizy wariancji (tabela 4), wszystkie okazały się statystycznie istotne, a więc średnie w grupach różnią się istotnie. W kolejnym kroku analizy dokonano testu rozsądnie istotnej różnicy (RIR) Tukeya dla zmiennej kredyty inwestycyjne, który potwierdził odchylenie średnich udziałów kredytów inwestycyjnych w strukturze portfela kredytowego w zależności od grupy wielkości banków. Dodatkowo na wykresie 4 przedstawiono graficzną interpretacje wyników przeprowadzonej analizy wa- 


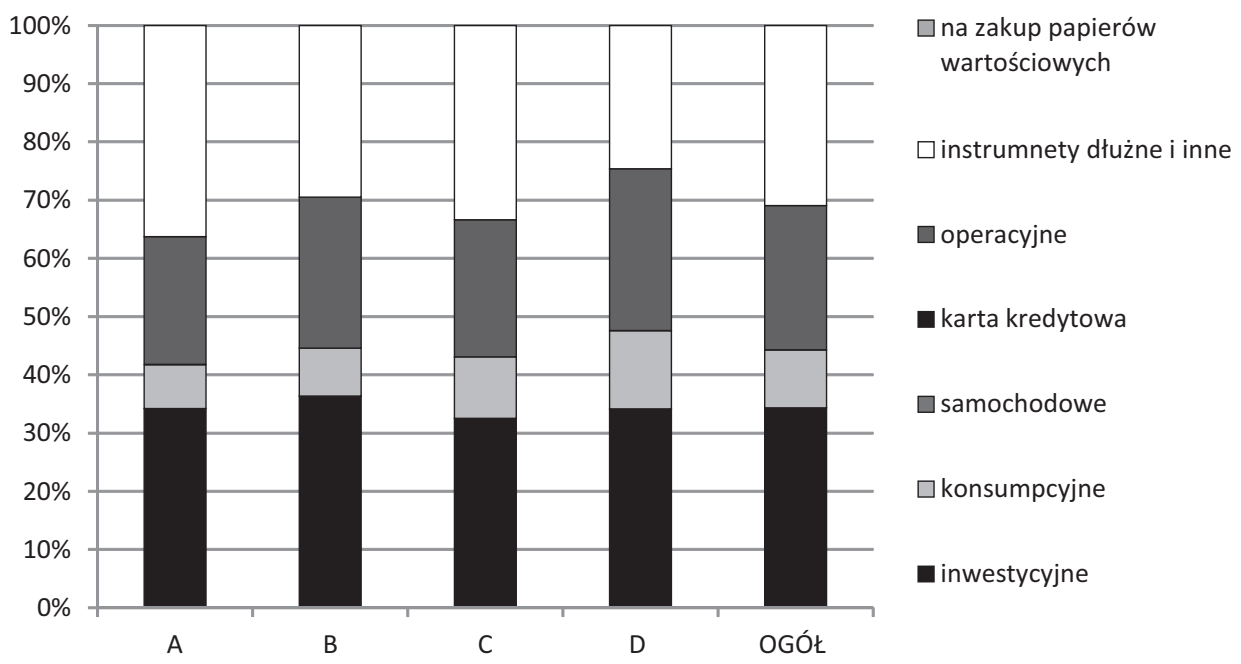

WYKRES 3. Średni udział udzielonych kredytów ze względu na rodzaj kredytu

Źródło: opracowanie własne.

TABELA 3. Test Levene’a jednorodności wariancji

\begin{tabular}{|l|c|c|c|c|c|c|}
\hline Rodzaj kredytu & $\begin{array}{c}\text { SS } \\
\text { efekt }^{1}\end{array}$ & $\begin{array}{c}\text { MS } \\
\text { efekt }^{2}\end{array}$ & $\begin{array}{c}\text { SS } \\
\text { błąd }\end{array}$ & $\begin{array}{c}\text { MS } \\
\text { błąd }\end{array}$ & $\begin{array}{c}\text { Wartość } \\
\text { testu F }\end{array}$ & $\begin{array}{c}\text { Poziom } \\
\mathrm{p}^{5}\end{array}$ \\
\hline konsumpcyjne & 0,019908 & 0,006636 & 0,099946 & 0,001922 & 3,45265 & 0,022968 \\
\hline $\begin{array}{l}\text { instrumenty } \\
\text { dłużne i inne }\end{array}$ & 0,017493 & 0,005831 & 0,493573 & 0,009492 & 0,61432 & 0,608800 \\
\hline samochodowe & 0,000001 & 0,000000 & 0,000001 & 0,000000 & 22,42417 & 0,000000 \\
\hline inwestycyjne & 0,011551 & 0,003850 & 0,393465 & 0,007567 & 0,50887 & 0,677904 \\
\hline $\begin{array}{l}\text { na zakup } \\
\text { papierów }\end{array}$ & 0,000000 & 0,000000 & 0,000000 & 0,000000 & - & - \\
\hline operacyjne & 0,027543 & 0,009181 & 0,253927 & 0,004883 & 1,88010 & 0,144400 \\
\hline karta kredytowa & 0,000004 & 0,000001 & 0,000010 & 0,000000 & 7,76506 & 0,000223 \\
\hline
\end{tabular}

${ }^{1}$ suma kwadratów pomiędzy grupami

${ }^{2}$ średnie kwadraty pomiędzy grupami

${ }^{3}$ suma kwadratów resztowa

${ }^{4}$ średnia suma kwadratów wewnątrz grup

${ }^{5}$ hipotezę zerowa odrzucamy, gdy $\mathrm{p}<0,05$.

Źródło: opracowanie własne. 
riancji, na którym punkty odpowiadają wartościom średnich w poszczególnych grupach banków, natomiast słupki odzwierciedlają granice ufności wokół średnich. Zgodnie z otrzymanymi wynikami najwyżej położona jest grupa A, a więc banki największe, która zadecydowała o odrzuceniu hipotezy zerowej, co oznacza, że co najmniej dwie średnie w grupie różniły się między sobą.

TABELA 4. Wyniki analizy wariancji dla wybranych zmiennych

\begin{tabular}{|l|c|c|c|c|c|c|}
\hline $\begin{array}{l}\text { Rodzaj } \\
\text { kredytu }\end{array}$ & SS efekt & MS efekt & SS błąd & MS błąd & $\begin{array}{c}\text { Wartość } \\
\text { testu F }\end{array}$ & ${\text { Poziom } \mathrm{p}^{1}}$ \\
\hline operacyjne & $2,91796 \mathrm{E}+16$ & $9,72656 \mathrm{E}+15$ & $4,22999 \mathrm{E}+16$ & $8,13460 \mathrm{E}+14$ & 11,95702 & 0,000005 \\
\hline inwestycyjne & $5,41868 \mathrm{E}+16$ & $1,80622 \mathrm{E}+16$ & $5,83064 \mathrm{E}+16$ & $1,12127 \mathrm{E}+15$ & 16,10866 & 0,000000 \\
\hline $\begin{array}{l}\text { instrumenty } \\
\text { dłużne i inne }\end{array}$ & $8,82410 \mathrm{E}+16$ & $2,94136 \mathrm{E}+16$ & $8,69354 \mathrm{E}+16$ & $1,67183 \mathrm{E}+15$ & 17,59365 & 0,000000 \\
\hline
\end{tabular}

${ }^{1}$ hipotezę zerowa odrzucamy, gdy $\mathrm{p}<0,05$.

Źródło: opracowanie własne.

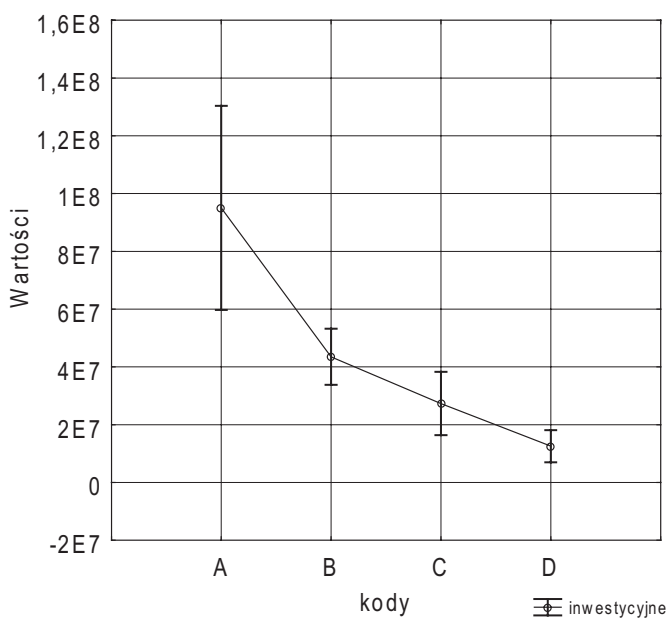

WYKRES 4. Interpretacja graficzna wyników analizy wariancji

Źródło: opracowanie własne.

\section{WNIOSKI}

Celem opracowania było sprawdzenie czy struktura rodzajowa udzielonych kredytów przez banki spółdzielcze, różni się w zależności od ich wielkości. W artykule postawiono do weryfikacji następującą hipotezę badawczą: struktura rodza- 
jowa kredytów zróżnicowana jest za względu na wielkość banku ${ }^{1}$ Na podstawie przeprowadzonych badań własnych oraz materiałów empirycznych sformułowano następujące wnioski:

1. Kredyty bankowe są bez wątpienia najważniejszym aktywem w strukturze sumy bilansowej banków spółdzielczych, zwłaszcza pod względem wartości. Wraz z rozwojem gospodarczym oraz intensyfikacją pozycji konkrecyjnej banków spółdzielczych względem innych instytucji bankowych oraz pożyczkowych wzrasta udział różnych rodzajów kredytów w portfelach kredytowych tych banków $(69,1 \%)$.

2. Pod względem średnich różnic w strukturze udzielnych kredytów między bankami o różnych wartościach sumy bilansowej największe rozróżnienie dotyczyło kredytów konsumpcyjnych. Najwyższy udział w tej grupie miały banki małe - grupa D $(13,40 \%)$, natomiast banki o najwyższej sumie bilansowej - grupa A, charakteryzowały się najniższym udziałem tego rodzaju kredytu $(7,5 \%)$ w strukturze portfela kredytowego. W przypadku kredytów inwestycyjnych w wolumenie udzielonych kredytów zajmowały podobny udział we wszystkich - średnio 34,3\% z odchyleniem +2,1p.p. (grupa B) do -1,8 p.p. (grupa C).

3. W przypadku takich kredytów jak kredyty samochodowe, kredyty w karcie kredytowej oraz konsumpcyjnie wystąpiły wariancje niejednorodne co uniemożliwiło przeprowadzenie dalszych obliczeń. Z jednej strony taki stan rzeczy może wynikać z niewielkiej wartości udziałów tych rodzajów kredytów, natomiast takie rodzaje kredytów jak inwestycyjne, operacyjne oraz instrumenty dłużne wykazały istotne różnice w średnich w poszczególnych grupach banków. Największe różnice w strukturach portfeli kredytowych zanotowano w grupie A, a więc banków o najwyższych sumach bilansowych. Natomiast najmniejsze w bankach małych (grupa D), o sumie bilansowej poniżej 91 tys. zł. Na podstawie przeprowadzonej analizy wariancji można stwierdzić, iż na tym etapie badań nie jest możliwe jednoznaczne określenie, że wielkość banku determinuje jego strukturę kredytową. Zatem odrzucono hipotezę, iż wielkość banku warunkuje strukturę jego portfela kredytowego. Co jednocześnie stanowi zaczątek do dalszych badań Autorów z tego zakresu.

\footnotetext{
${ }^{1}$ Przeprowadzona analiza obejmowała działalność tylko wybranej próby, tj. na potrzeby przeprowadzenia analizy wylosowano dane 56 banków spółdzielczych (co stanowiło $10 \%$ populacji wszystkich banków spółdzielczych, funkcjonujących w polskim sektorze bankowym), które gromadzone są i przetwarzane przez Związek Rewizyjny Banków Spółdzielczych. Uwzględniono stan ze stycznia 2016 roku. Dlatego też sformułowane wnioski z przeprowadzonych badań mają charakter fragmentaryczny, a uzyskane wyniki badań nie mogą być uogólnione na cały sektor bankowości spółdzielczej w Polsce.
} 


\title{
Spis literatury
}

CAPIGA M. 2008: Bankowość, Wydawnictwo Akademii Ekonomicznej, Katowice.

CAPIGA M., HARASIM J., SZUSTAK G. 2005: Finanse banków, Stowarzyszenie Księgowych w Polsce, Warszawa.

DOBOSIEWICZ Z. 2003: Bankowość, Polskie Wydawnictwo Ekonomiczne, Warszawa.

GRZYWACZ J. 2006: Podstawy bankowości, Difin, Warszawa.

HILL T., LEWICKI P., 2006: Statistics. Methods and Application. A Comprensive References for Sciences, Industry and Fata Mining, StatSoft, USA.

JANC A., KOTLIŃSKI G. 1999: Wykorzystanie bankowości elektronicznej w rozwoju usług, Bank, nr 9.

JAWORSKI W. L., ZAWADZKA Z. 2005: Bankowość. Podręcznik akademicki, Poltext, Warszawa.

KOMISJA NAZDORU FINANSOWEGO, 2012: Risk management for electronic banking and electronic money activities, Basel, http://www.bis.org/publ/bcbs35.pdf (dostęp: 05.08.2017 r.).

KRYSIAK A., STANISZEWSKA A., WIATR M. S. 2015: Zarządzanie portfelem kredytowym banku, Szkoła Główna w Warszawie - Oficyna wydawnicza, Warszawa.

SŁOWNIK FINANSÓW I BANKOWOŚCI 2008, Wydawnictwo Naukowe PWN, Warszawa

WIATR M. 2001: Zarządzanie indywidualnym ryzykiem kredytowym. Elementy systemu, Szkoła Główna w Warszawie - Oficyna wydawnicza, Warszawa.

USTAWA Prawo bankowe (Dz.U. Dz. U. z 2016 r. poz. 1948 ze zm.).

ZALESKA M. 2013: Bankowość, C.H. Beck, Warszawa.

\section{THE VARIATION OF CRDIT STRUCTURE AND THE BANK'S SIZE ON THE EXAMPLE OF SELECTED COOPERATIVE BANKS}

\begin{abstract}
The cooperative banks to be competitive in banking sector relative to the commercial banks and others banking institution had to pursue of customers' credit request. It seems, that bank granted investments loans, which are quantified by smaller dynamics than retail loans. However individual bank's commitment in this situation is relatively higher. Therefore is a question whether the genre structure of granted loans is being determined by the size of the bank? The aim of the elaboration was to determine the diversification level of loans' structure due to bank's size. The analysis of variance confirmed that existing essential statically of differences in the structure of investment loans and operating and debt instruments, however in other loans' groups in the structure weren't confirmed any differences depending on the size of the bank.
\end{abstract}

Key word: cooperative banks, credit portfolio structure, investment loans. 